\title{
PENGEMBANGAN MULTIMEDIA INTERAKTIF PEMBELAJARAN BAHASA INGGRIS MATERI TEKS DESKRIPTIF UNTUK SISWA SMP/MTs
}

\author{
Erma Riana, Abdul Gafur \\ PPs UNY, Fakultas Ilmu Sosial UNY \\ ermariana88@gmail.com, abdul_gafur@uny.ac.id
}

\begin{abstract}
Abstrak
Penelitian ini bertujuan untuk: (1) menghasilkan multimedia pembelajaran interaktif bahasa Inggris materi teks dekriptif untuk siswa SMP/MTs, (2) mengetahui tingkat kelayakan dan efektivitas produk multimedia pembelajaran interaktif yang dikembangkan untuk pembelajaran bahasa Inggris materi teks dekriptif untuk siswa SMP/MTs. Penelitian ini merupakan penelitian pengembangan $(R \& D)$ yang diadaptasi dari model Borg and Gall dan model desain pembelajaran Dick \& Carey yang terdiri dari analisis kebutuhan, desain pembelajaran, pengembangan produk, validasi dan revisi produk. Teknik pengumpulan data menggunakan observasi, kuesioner, dan tes. Data yang diperoleh dianalisis secara deskriptif kuantitatif. Efektivitas produk dianalisis menggunakan rumus $N$-gain (hasil belajar yang dinormalisasi). Hasil penelitian menunjukkan: (1) produk yang dihasikan adalah multimedia interaktif yang terdiri dari kompetensi, materi, glossary, evaluasi, dan games, (2) produk yang dikembangkan layak digunakan sebagai alat bantu pembelajaran; (3) efektivitas pengembangan produk termasuk dalam kategori tinggi.
\end{abstract}

Kata kunci: pengembangan multimedia, pembelajaran Bahasa Inggris

\section{DEVELOPING INTERACTIVE MULTIMEDIA OF ENGLISH LEARNING IN DESCRIPTIVE TEXT MATERIALS FOR STUDENTS OF SMP/MTS}

\author{
Erma Riana, Abdul Gafur \\ PPs UNY, Fakultas Ilmu Sosial UNY \\ ermariana88@gmail.com, abdul_gafur@uny.ac.id
}

\begin{abstract}
This research aims to: (1) produce interactive multimedia of English learning in descriptive text materials for students of SMP/MTs, (2) determine the feasibility and the effectiveness of the developed product. The study is a research and development $(R \& D)$ adapted from Borg and Gall model and instructional design model from Dick $\mathcal{E}$ Carey that consist of need assessment, instructional design, initial product development, validation and revision of product. The data were analyzed using descriptive quantitative technique. The effectiveness of product was analyzed by formula N-gain (normalized learning gain). The results of this research shows that: (1) the product resulted was interactive multimedia that consist of competencies, materials, glossaries, and games, (2) product developed is feasible to be used as a learning tools (3) the effectiveness of the product development gets a high category.
\end{abstract}

Keywords: Multimedia development, English learning 



\section{Pendahuluan}

Kemajuan teknologi dan informasi telah berkembang pesat dan mempengaruhi berbagai bidang, salah satunya yaitu bidang pendidikan. Pemanfaatan teknologi informasi dan komunikasi dapat digunakan sesuai dengan fungsinya. Berbagai aplikasi teknologi informasi dan komunikasi sudah tersedia dan siap digunakan serta dimanfaatkan secara optimal untuk keperluan dalam bidang pendidikan. Penggunaan teknologi informasi dan komunikasi merupakan salah satu faktor penting yang memungkinkan kecepatan transfor-masi ilmu pengetahuan kepada para pe-serta didik atau generasi bangsa yang lebih luas.

Tidak semua kegiatan pendidikan selalu mendapatkan hasil yang optimal, kadang kala juga mendapatkan kegagalan. Keberhasilan atau kegagalan suatu pendidikan pada dasarnya dapat dilihat dari perubahan sikap dan prestasi hasil pembelajaran yang telah dicapai siswa setelah proses pembelajaran. Agar kualitas pembelajaran dapat tercapai, sebaiknya guru memerlukan informasi tentang karakteristik mata pelajaran tersebut.

Pelajaran Bahasa Inggris merupakan salah satu pelajaran yang mempunyai empat aspek dalam pembelajarannya, yaitu kemampuan membaca, menulis, mendengar, dan berbicara. Apabila empat aspek tersebut dapat terpenuhi maka pembelajaran berbahasa menjadi lebih efektif. Salah satu kunci keberhasilan dalam proses belajar mengajar adalah menghadirkan siswa dalam kondisi yang santai dan menyenangkan tetapi tujuan pembelajaran tercapai.

Prinsip pembelajaran pada kurikulum 2013 pada mata pelajaran bahasa Inggris menggunakan pendekatan pembelajaran saintifik yang menekankan pada proses pencarian pengetahuan daripada transfer pengetahuan. Peserta didik dipandang sebagai subjek belajar yang perlu dilibatkan secara aktif dalam proses pembelajaran, pendidik hanyalah sebagai fasilitator yang membimbing dan mengkoor- dinasikan kegiatan belajar peserta didik (Kemendikbud, 2013, p.6).

Materi teks deskriptif merupakan salah satu mata pelajaran bahasa Inggris yang menggunakan pendekatan saintifik. Materi ini merupakan materi yang sulit dipelajari oleh siswa karena materi atau topik yang disajikan tidak didukung dengan contoh-contoh nyata yang relevan dengan topik tersebut. Kesulitan yang dihadapi oleh siswa merupakan kendala utama dalam proses pembelajaran materi ini. Kendala yang dihadapi diantaranya kurangnya latihan dan minat belajar dari dalam diri siswa, rancangan atau design pembelajaran yang disajikan kurang menarik dan terkesan monoton, serta belum tersedianya media pembelajaran yang dapat memfasilitasi kegiatan pembelajaran khususnya materi teks deskriptif.

Smaldino, Lowther, \& Russel (2011, p.30) menjelaskan beberapa setrategi mengajar yang bisa digunakan di dalam kelas yang dapat meningkatkan kualitas pembelajaran. Strategi-strategi tersebut diantaranya teknik presentasi, demonstrasi, latihan dan praktik, tutorial, diskusi, belajar kooperatif, permainan, simulasi, penemuan, penyelesain masalah, pembelajaran seperti teknik ceramah, diskusi, dan penyelesain masalah. Keputusan memilih strategi tersebut bergantung pada sejumlah faktor termasuk hasil belajar siswa, usia siswa, dan kenyamanan dalam menerapkan strategi tersebut.

Media komputer bisa jadi salah satu alternatif yang bisa digunakan oleh guru dengan dengan tujuan membuat siswa lebih aktif dan tertarik untuk mengikuti proses pembelajaran. Salah satu wujud nyata penggunaan teknologi dan informasi pada saat ini yaitu pemanfaatan media komunikasi pembelajaran komputer yang berfungsi sebagai gudang ilmu dan alat bantu pembelajaran yang bertujuan untuk menyampaikan pesan pembelajaran. Media komunikasi yang dimanfaatkan dalam proses komunikasi pembelajaran diharapkan dapat mengefektifkan proses penyampaian pesan (Darmawan, 2012, p.25). 
Pengembangan produk multimedia pembelajaran merupakan solusi alternatif sebagai pemanfaatan sumber belajar yang dapat digunakan oleh siswa sebagai media dalam pembelajaran. Berdasarkan uraian dan berbagai permasalahan di atas, maka hal tersebut menjadi alasan bagi peneliti melakukan penelitian dalam hal pengembangan produk multimedia pembelajaran dengan rumusan masalah yaitu; (1) bagaimana menghasilkan multimedia pembelajaran interaktif Bahasa Inggris materi teks dekriptif untuk siswa SMP/MTs, (2) bagaimana tingkat kelayakan dan efektivitas produk multimedia pembelajaran interaktif bahasa Inggris materi teks dekriptif untuk siswa SMP/MTs yang dikembangkan. Tujuan dari penelitian ini adalah: (1) menghasilkan multimedia pembelajaran interaktif Bahasa Inggris materi teks deskriptif untuk siswa SMP/MTs, (2) mengetahui tingkat kelayakan dan efektivitas produk multimedia pembelajaran interaktif Bahasa Inggris materi teks dekriptif untuk siswa SMP/MTs yang dikembangkan.

Phillips $(1997$, p.8) mendefenisikan multimedia sebagai gabungan teks, gambar, suara, animasi, dan video; beberapa komponen tersebut atau bahkan seluruh komponen dimasukkan kedalam program yang koheren. Multimedia pembelajaran secara umum diartikan sebagai representasi penyampaian materi dengan menggabungkan beberapa media sebagai alat bantu pembelajaran berbentuk teks, grafik, animasi, gambar, video, suara, perekayasa, dan lainnya dengan tujuan untuk meningkatkan pembelajaran.

Phillips (1997, p.12) menjelaskan manfaat penggunaan multimedia pembelajaran berpotensial untuk menciptakan gaya belajar multisensori dan pada saat bersamaan mendorong siswa untuk mengeluarkan gaya belajar mereka sebanyak mungkin. Peran multimedia sangat penting terutama untuk efektivitas pembelajaran. Peran multimedia tampak pada pembelajaran mandiri yang memberi ruang gerak bagi siswa untuk aktif membangun pengetahuan, keterampilan, dan sikap mereka.
Pembelajaran aktif siswa, berdampak pada kurangnya pembelajaran yang berpusat pada guru (teacher centered). Multimedia juga berperan melayani perbedaan gaya belajar individu dalam memahami materi yang disajikan.

Prinsip-prinsip multimedia pembelajaran merupakan resep dalam mendesain presentasi multimedia yang diterapkan sesuai dengan teori kognitif multimedia learning. Multimedia dapat meningkatkan pembelajaran apabila dirancang berdasarkan desain pesan dan juga prinsip-prinsip multimedia pembelajaran.

Mayer (2009, pp.270-271) memberi kontribusi yang sangat penting dalam memahami bagaimana proses kognitif dalam menyampaikan informasi visual dan auditori bisa memberi efek dalam pembelajaran. Pengembangan produk sesuai dengan prinsip yang dikemukakan Mayer dengan tujuan membantu meningkatkan proses belajar mengajar. Masing-masing prinsip diuraikan pada Tabel 1.

Tabel 1. Prinsip Multimedia Pembelajaran

\begin{tabular}{|c|c|c|}
\hline No & Prinsip & Deskripsi \\
\hline 1 & Mult & $\begin{array}{l}\text { Siswa bisa belajar lebih baik dengan } \\
\text { kata-kata dan gambar-gambar dari- } \\
\text { pada dengan kata-kata saja. }\end{array}$ \\
\hline 2 & $\begin{array}{l}\text { Prinsip } \\
\text { keterdekatan } \\
\text { ruang }\end{array}$ & $\begin{array}{l}\text { Siswa bisa belajar lebih baik saat kata- } \\
\text { kata dan gambar-gambar terkait disa- } \\
\text { jikan saling berdekatan daripada ber- } \\
\text { jauhan di halaman atau di layar }\end{array}$ \\
\hline 3 & $\begin{array}{l}\text { Prinsip } \\
\text { keterdekatan } \\
\text { waktu }\end{array}$ & $\begin{array}{l}\text { Siswa bisa belajar lebih baik saat kata- } \\
\text { kata dan gambar-gambar disajikan se- } \\
\text { cara simultan (bersamaan) daripada } \\
\text { suksesif (bergantian) }\end{array}$ \\
\hline 4 & $\begin{array}{l}\text { Prinsip } \\
\text { koherensi }\end{array}$ & $\begin{array}{l}\text { Siswa bisa belajar lebih baik saat kata- } \\
\text { kata, gambar-gambar, atau suara- } \\
\text { suara ekstra atau tambahan dibuang } \\
\text { daripada dimasukkan. }\end{array}$ \\
\hline 5 & $\begin{array}{l}\text { Prinsip } \\
\text { modalitas }\end{array}$ & $\begin{array}{l}\text { Siswa bisa belajar lebih baik dari ani- } \\
\text { masi dan narasi daripada dari animasi } \\
\text { dan teks on-screen. }\end{array}$ \\
\hline 6 & $\begin{array}{l}\text { Prinsip } \\
\text { redudansi }\end{array}$ & $\begin{array}{l}\text { Siswa bisa belajar lebih baik daripada } \\
\text { animasi dan narasi daripada dari } \\
\text { animasi, narasi, dan teks on-screen. }\end{array}$ \\
\hline 7 & $\begin{array}{l}\text { Prinsip } \\
\text { perbedaan } \\
\text { individual }\end{array}$ & $\begin{array}{l}\text { Pengaruh desain lebih kuat terhadap } \\
\text { siswa berpengetahuan rendah dari- } \\
\text { pada berpengetahuan tinggi dan ter- } \\
\text { hadap siswa berkemampuan spasial } \\
\text { tinggi daripada berspasial rendah }\end{array}$ \\
\hline
\end{tabular}


Bahasa merupakan alat komunikasi yang berupa sistem lambang bunyi yang dihasilkan alat ucap manusia yang masingmasing dan mempunyai makna. Brown (1987, p.4) menyatakan bahasa adalah suatu sistem komunikasi menggunakan bunyi yang diucapkan melalui organ-organ ujaran dan didengar diantara anggotaanggota masyarakat, serta menggunakan pemrosesan simbol-simbol vokal dengan makna konvensional secara arbitrer. Arbitrer berarti dipilih secara acak tanpa alasan sehingga ciri khusus bahasa tidak dapat diramalkan secara tepat. Pentingnya pembelajaran bahasa diungkapkan

Harmer (2007, pp.270-275) membagi keterampilan berbahasa menjadi dua, yaitu ketrampilan reseptif meliputi keterampilan menyimak dan keterampilan membaca, serta keterampilan produktif yang terdiri dari keterampilan menulis dan keterampilan berbicara. Pendapat yang senada juga dijelaskan oleh Tompkins dan Hoskisson (1995, p.19) yang menerangkan bahwa keempat keterampilan berbahasa berkembang secara berurutan dimulai dari menyimak, berbicara, membaca, dan menulis, Menyimak dan berbicara adalah keterampilan yang dipelajari sebelum memasuki sekolah, sedangkan membaca dan menulis adalah keterampilan yang dipelajari ketika berada di bangku sekolah.

Towndrow \& Vallace (2004, pp.3742) mengemukakan pembelajaran bahasa menggunakan komputer yang dalam perkembangannya disebut Computer Assisted Language Learning (CALL) dikategorikan dalam tiga fase, yakni behaviorist CALL, communicative CALL, dan integrative CALL.

Fungsi komputer pada fase behaviorist CALL melatih, memonitor, menuntun, mengevaluasi, dan melaporkan kemajuan belajar peserta didik. Pada fase communicative CALL komputer menjadi alat untuk merangsang peserta didik untuk berpikir dan berdiskusi secara kritis. Pada fase integrative call pengajaran bahasa dengan memanfaatkan sarana penunjang yang ada seperti e-mail, papan bulletin, internet relay chat, dan multi user domain object oriented dapat digunakan di lingkungan belajar bahasa. Sebagai akibat dari kondisi ini adalah komputer mediated communication dapat mempermudah pendekatan integratif dari penggunaan teknologi dalam pengajaran bahasa.

Komputer merupakan salah satu sarana efektif untuk menyajikan materi bahasa Inggris kepada peserta didik untuk mencapai tujuan pembelajaran. Komputer dapat membantu siswa mengeksplorasi, belajar, mengatur pembelajaran, dan mengkonstruksi pengetahuan sesuai dengan kebutuhan dan kepentingan siswa dalam memfasilitasi pembelajaran yang dibutuhkan (Khamkhien, 2012, p.57).

Alat bantu teknologi dapat memberikan sejumlah kesempatan kepada peserta didik untuk mengembangkan kompetensi linguistiknya, yaitu dengan merekonstruksi teks, mengadaptasikan model teks untuk peserta didik dan tujuan yang ingin dicapai, mencoba untuk menggunakan bahasa, mengkomunikasikan informasi dalam bahasa target untuk peserta didik dan tujuan yang ditetapkan.

Fungsi teknologi dapat mencari informasi berdasarkan permintaan lisan atau tertulis, memberikan informasi yang diterima, berhubungan dengan penutur asli Bahasa Inggris, menggunakan sumbersumber untuk mengeksplorasikan dan mengekstasikan informasi yang relevan, menggunakan sumber-sumber referensi, mempraktekkan bahasa untuk mencapai akurasi yang lebih baik (Pachler dan Field, 1997, p. 248).

Kegiatan pembelajaran pada mata pelajaran Bahasa Inggris melalui pendekatan saintifik dilakukan melalui mengamati, menanya, mengeksplorasi, mengasosiasi, dan mengomunikasikan (kemdikbud, 2013, pp. 8-9). Kegiatan mengamati bertujuan agar pembelajaran berkaitan erat dengan konteks situasi nyata yang dihadapi dalam kehidupan sehari-hari yang mencakup kegiatan mendengarkan paparan, membaca teks, memperhatikan fungsi sosial, struktur teks, unsur kebahasaan, dan format penyampaian atau penulisannya. 
Kegiatan menanya merupakan salah satu proses membangun pengetahuan peserta didik dalam bentuk konsep, prinsip, prosedur, hukum dan teori, hingga berfikir metakognitif dengan tujuan agar peserta didik berfikir secara kritis, logis, dan sistematis. Pembelajaran Bahasa Inggris pada kegiatan menanya dapat dilakukan dengan menanyakan perbedaan bentuk paparan secara lisan maupun tertulis dalam bahasa Inggris dan bahasa Indonesia termasuk perbedaan penggunaanya, perbedaan pola-pola kalimat, dan isi wacana seperti gagasan pokok, informasi tertentu, informasi rinci, rujukan kata, dsb.

Kegiatan mengeksplorasi dilakukan untuk melatih kemampuan berbahasa peserta didik melalui kegiatan simulasi, bermain peran, dan kegiatan lain yang terstruktur. Selanjutnya kegiatan mengasosiasi bertujuan untuk membangun kemampuan berfikir dan bersikap ilmiah. Kegiatan tersebut dapat dirancang oleh pendidik melalui situasi yang direkayasa dalam kegiatan berkelompok sehingga peserta didik melakukan aktifitas seperti menganalisis teks, mengelompokkan, membuat kategori, menyimpulkan, membandingkan berbagai ungkapan, struktur teks, unsur kebahasaan, mendiskusikan isi wacana, serta memperoleh balikan dari pendidik.

Kegiatan mengomunikasi merupakan kegiatan terahir pada pendekatan saintifik. Kegiatan ini bertujuan untuk menyampaikan hasil konseptualisasi dalam bentuk lisan/tulis seperti mendemonstrasikan, menuliskan, memaparkan, menyunting hasil karya teman, mempublikasikan hasil karya pada majalah dinding, buletin sekolah, learning journal, blog sekolah, dan sebagainya.

Gerot \& Wignell (1994, p.208) mendefinisikan tulisan deskriptif merupakan sejenis teks yang bertujuan memberikan informasi. Secara umum tulisan deskrptif berupa benda, hewan, orang, dan yang lainnya seperti binatang atau orang yang kita kenal baik. Jadi, bisa dikatakan bahwa descriptive text ini adalah teks yang men- jelaskan tentang orang, benda, binatang, dan lainnya secara umum dengan tujuan memberikan informasi.

Hammond (1992, p.78) menjelaskan susunan umum dalam descriptive text yaitu fokus pada apa yang akan dijelaskan, menggunakan kalimat simple present tense, simple past tense, kata kerja being and having, menggunakan kata sifat, menggunakan frasa kata benda secara khusus untuk memberi informasi tentang subjek, menggunakan kata kerja, menggunakan kata keterangan untuk memberikan informasi tambahan tentang sifat seseorang, dan menggunakan bahasa figurative.

\section{Metode Penelitian}

Penelitian ini multimedia merupakan penelitian pengembangan atau $R e-$ search and Development (R\&D) yang bertujuan menghasilkan alat bantu pembelajaran berupa produk multimedia pembelajaran bahasa Inggris materi teks deksriptif untuk siswa SMP/MTs yang difokuskan pada pengajaran berbantuan komputer ( $\mathrm{CAI}=$ Computer Assisted Instruction) berdasarkan kurikulum 2013.

Model yang digunakan dalam penelitian yaitu model yang diadaptasi dari Borg and Gall (1983, p. 775) dan model desain pembelajaran Dick \& Carey (2001, pp.6-9) yang terdiri dari analisis kebutuhan, desain pembelajaran, pengembangan produk, validasi dan revisi produk.

Prosedur pengembangan produk multimedia pembelajaran dalam penelitian ini dapat dijelaskan dalam Gambar 1.

Tahap ini bertujuan untuk menguji sejauh mana produk yang dikembangkan memenuhi kriteria pembelajaran dan kriteria performance. Uji coba produk sebagai bagian dari tahap pengembangan dilakukan melalui tiga tahap yaitu uji coba satu-satu. Uji coba kelompok kecil, dan uji coba lapangan. Setelah produk yang dikembangkan dinilai layak digunakan menurut ahli materi, ahli media, dan uji coba lapangan, maka dilakukan evaluasi desain eksperimen satu kelompok dengan 
pretest dan postest yang bertujuan untuk mengetahui efektivitas produk tersebut.
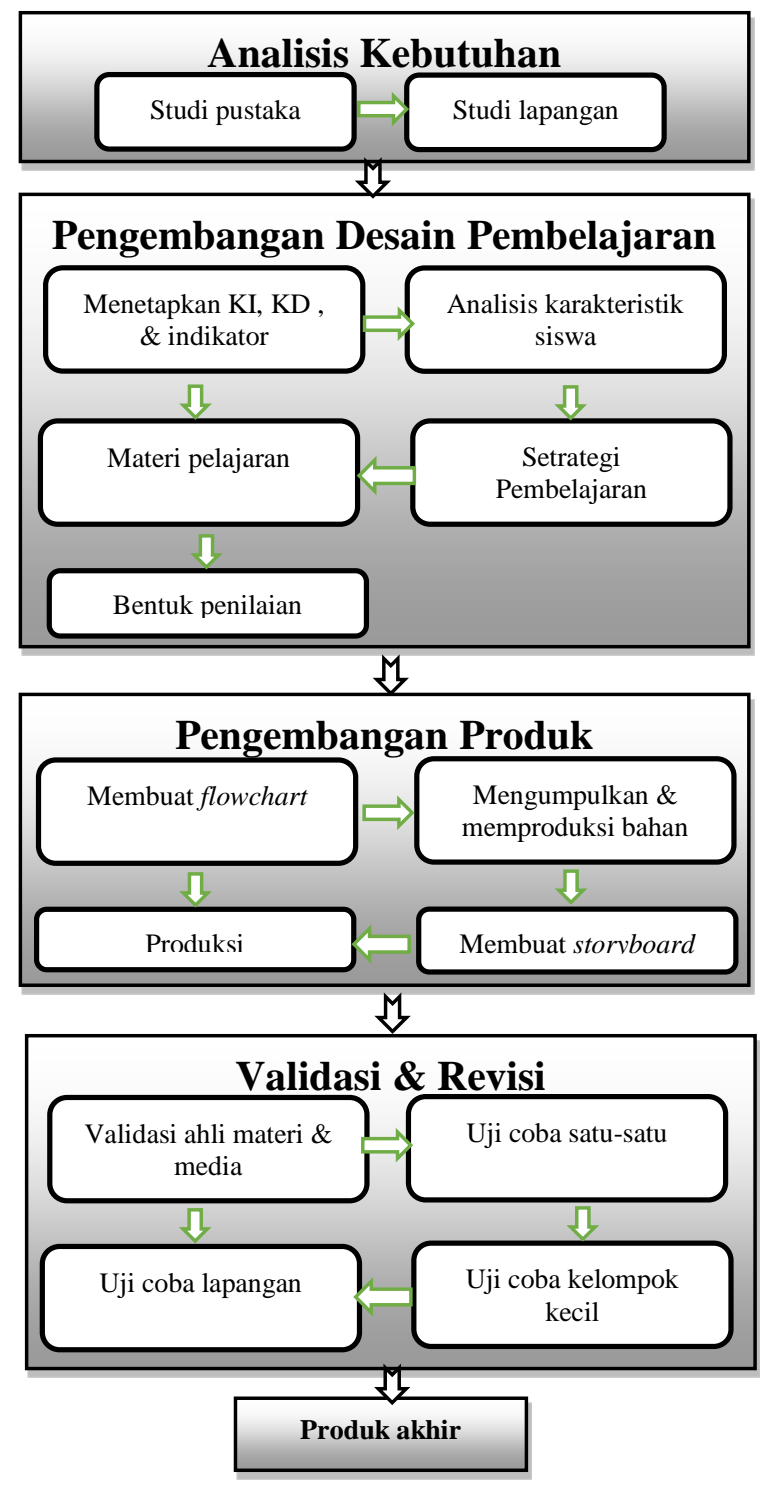

Gambar 1. Diagram prosedur pengembangan dari model Borg \& Gall, Dick \& Carey

Subjek uji coba dalam penelitian ini adalah siswa kelas VII SMPN 3 Kalasan Yogyakarta tahun ajaran 2013/2014. Subjek uji coba berjumlah tiga siswa pada uji coba perorangan, sembilan siswa pada uji coba kelompok kecil, dan 30 siswa pada uji coba lapangan operasional.

Teknik pengumpulan data selama proses pengembangan produk menggunakan teknik observasi, angket atau kuesioner, dan tes. Observasi dilakukan pada saat penelitian pendahuluan (prasurvey) dengan cara pengumpulan informasi tentang kondisi, sarana dan prasarana pembelajaran di sekolah tempat uji coba dilakukan. Observasi dilakukan untuk mendapatkan data tentang bagaimana kegiatan pembelajaran Bahasa Inggris di sekolah tersebut.

Angket digunakan untuk mengetahui ketepatan rancangan produk sebagai program multimedia pembelajaran. Ada empat angket dalam penelitian ini yaitu angket analisis kebutuhan, angket untuk ahli materi, angket untuk ahli media, dan angket untuk siswa. Angket analisis kebutuhan diberikan kepada guru dengan tujuan menjaring informasi mengenai penggunaan jenis sumber belajar, proses pembelajaran, penggunaan CAI dalam proses pembelajaran.

Angket untuk ahli materi dan ahli media berupa kuesioner berisi butir-butir pernyatan penilaian terhadap multimedia yang menggunakan skala interval 5 . Angket untuk ahli materi difokuskan aspek pembelajaran dan aspek isi. Angket untuk ahli media difokuskan pada aspek tampilan dan pemrograman. Angket untuk siswa digunakan untuk menilai kelayakan program multimedia dalam pembelajaran yang sebenarnya di dalam kelas. Instrumen ini menggunakan skala interval 5 dengan dengan jenis pernyatan-pernyataan yang dikhususkan pada aspek pembelajaran, tampilan, dan materi yang bersifat umum.

Instrumen yang dikembangkan selanjutnya berbentuk tes yang diberikan kepada siswa dengan tujuan menilai efektivitas program multimedia dalam pembelajaran dan menentukan apakah program multimedia yang dikembangkan berhasil atau tidak ditinjau dari pencapaian skor tes. Instrumen penilaian ini berupa pertanyaan berjumlah 10 soal pilihan ganda mencakup satu kompetensi sesuai dengan rumusan kompetensi inti dan kompetensi dasar. Tes diberikan sebelum multimedia digunakan (pretest) dan setelah multimedia digunakan (postest).

Teknik analisis data kelayakan produk multimedia pembelajaran menggunakan skala Likert. Data hasil penelitian be- 
rupa tanggapan ahli media, ahli materi, dan siswa tentang kualitas produk yang dikembangkan ditinjau dari aspek pembelajaran, aspek materi, dan aspek media. Data berupa komentar, saran revisi, dan hasil pengamatan selama proses uji coba dianalisis secara deskriptif kualitatif dan disimpulkan sebagai masukan untuk memperbaiki atau merevisi produk. Data berupa skor tanggapan ahli media, ahli materi, dan siswa yang diperoleh dari kuesioner dianalisis secara deskriptif kuantitatif.

Skor yang diperoleh kemudian dikonversikan menjadi nilai dengan skala 5 . Skala 5 dalam teknik statistik penelitian dan pengembangan ini yaitu $A=$ sangat baik, angka $B=$ baik, angka $C=$ cukup baik, angka $D=$ kurang baik, dan $E=$ sangat kurang. Acuan pengubahan skor menjadi skala lima disajikan pada Tabel 2.

Tabel 2. Kriteria Penilaian

\begin{tabular}{cccc}
\hline \multirow{2}{*}{ Nilai } & \multicolumn{2}{c}{ Skor } & \multirow{2}{*}{ Kriteria } \\
\cline { 2 - 3 } & \multicolumn{1}{c}{ Rumus } & Perhitungan & \\
\hline 5 & $\mathrm{X}>\mathrm{Xi}+1,8 \mathrm{SBi}$ & $\mathrm{X}>4,21$ & sangat baik \\
4 & $\mathrm{Xi}+0.6 \mathrm{SBi}<\mathrm{X} \leq \mathrm{Xi}+1,8 \mathrm{SBi}$ & $3,4<\mathrm{X} \leq 4,21$ & baik \\
3 & $\mathrm{Xi}+0.6 \mathrm{SBi}<\mathrm{X} \leq \mathrm{Xi}+0,6 \mathrm{SBi}$ & $2,60<\mathrm{X} \leq 3,40$ & cukup \\
2 & $\mathrm{Xi}-1,8 \mathrm{SBi}<\mathrm{X} \leq \mathrm{Xi}-0,6 \mathrm{SBi}$ & $1,79<\mathrm{X} \leq 2,60$ & kurang \\
1 & $\mathrm{X}>\mathrm{Xi}-1,8 \mathrm{SBi}$ & $\mathrm{X} \leq 1,79$ & sangat kurang \\
\hline
\end{tabular}

Peningkatan hasil belajar yang terjadi sebelum dan sesudah menggunakan multimedia dihitung menggunakan rumus (N-gain) yang ditentukan berdasarkan ratarata gain score yang dinormalisasi (g) yaitu perbandingan dari skor gain. Peningkatan hasil belajar (gain score) adalah skor yang diperoleh siswa dari pretest dan posttest sedangkan skor gain maksimum yaitu skor gain tertinggi yang diperoleh siswa. Ratarata gain yang dinormalisasi (N-gain) (Hake, 1998, p.2) dinyatakan oleh persamaan sebagai berikut:

$$
g=\frac{\text { S post }- \text { S pre }}{\text { S maks }- \text { S pre }}
$$

Keterangan :

$S$ post : Rata-rata Skor Postes

$S$ pre : Rata-rata Skor Pretes

$S$ maks : Skor Maksimal
Nilai yang sudah diperoleh selanjutnya diinterpretasikan dalam tabel klasifikasi gain score (Hake, 1998, p.3) dengan kriteria sebagaimana disajikan pada Tabel 3.

Tabel 3. Klasifikasi Nilai Gain

\begin{tabular}{lc}
\hline Nilai & Klasifikasi \\
\hline$(\mathrm{N}$-gain $) \geq 0,7$ & Tinggi \\
$0,7<(\mathrm{N}-$ gain $) \geq 0,3$ & Sedang \\
$(\mathrm{N}$-gain $)<0,3$ & Rendah \\
\hline
\end{tabular}

\section{Hasil Penelitian}

\section{Hasil Pengembangan}

Kegiatan pada tahap ini dilakukan melalui empat tahap yaitu analisis kebutuhan, desain pembelajaran, pengembangan produk, validasi dan revisi produk. Tahap analisis kebutuhan dilaksanakan melalui studi pustaka dan studi lapangan. Kegiatan studi pustaka diperoleh data yaitu; nilai Bahasa Inggris pada kompetensi tertentu tidak sesuai dengan tujuan yang ditentukan. Sebagian hasil nilai siswa pada materi teks deskriptif di bawah standar KKM SMP N 3 Kalasan yaitu sebesar 7,5.

Salah satu penyebabnya yaitu terbatasnya sumber belajar yang mereka peroleh di dalam kelas. Penggunaan multimedia pembelajaran interaktif sebagai sumber belajar selain buku-buku mata pelajaran memberikan pengaruh yang positif terhadap proses dan hasil pembelajaran. Disamping itu, penggunaan komputer dalam pembelajaran yang ada di sekolah dapat dioptimalkan.

Kegiatan studi lapangan di SMPN 3 Kalasan Yogyakarta diperoleh data atau gambaran bahwa sebagian siswa belum fasih melafalkan dan membaca kalimat atau paragraf Bahasa Inggris, dan kurang percaya diri dengan kemampuan tata bahasa yang digunakan. Peserta didik juga terlihat jenuh dan bosan ketika mengikuti pelajaran bahasa Inggris karena rancangan atau design yang disajikan kurang menarik dan terkesan monoton, sebagian hasil nilai 
siswa pada materi tertentu atau kompetensi tertentu dibawah dari standar yang ditentukan, dan siswa kurang senang, tidak aktif, dan tidak fokus dalam menerima pembelajaran Bahasa Inggris.

Sekolah SMPN 3 Kalasan sudah memiliki fasilitas belajar yang cukup memadai diantaranya yaitu laboratorium komputer yang belum digunakan dan dimanfaatkan secara optimal untuk pembelajaran. Untuk mendukung atau mengoperasikan multimedia yang dikembangkan

Setelah melakukan analisis kebutuhan terhadap proses pembelajaran tahap selanjutnya yaitu desain pembelajaran. Tahap ini mengacu pada model desain pembelajaran Dick \& Carey (2001, pp.6-9) dimulai dari menentukan kompetensi inti dan kompetensi dasar, menetukan indikator keberhasilan, mengidentifikasi karakteristik awal siswa menentukan strategi pembelajaran, menentukan materi, dan mengembangkan dan melaksanakan evaluasi

Pada tahap pertama diperoleh informasi bahwa kompetensi inti (KI) yang harus dicapai adalah mencoba, mengolah, dan menyaji berbagai hal dalam ranah konkret (menggunakan, mengurai, merangkai, memodifikasi, dan membuat) dan ranah abstrak menulis, membaca, menghitung, menggambar, dan mengarang) sesuai dengan yang dipelajari di sekolah dan dari berbagai sumber lain yang sama dalam sudut pandang/teori. Kompetensi dasar (KD) yang harus dicapai peserta didik yaitu; menyusun teks deskriptif lisan dan tulis sangat pendek dan sederhana tentang orang, binatang, dan benda, dengan memperhatikan fungsi sosial, struktur teks, dan unsur kebahasaan, secara benar dan sesuai dengan konteks, selanjutnya menangkap makna dalam teks deskriptif lisan dan tulis sangat pendek dan sederhana.

Tahap kedua yaitu menentukan indikator keberhasilan siswa. Indikator yang ditentukan ialah: siswa dapat mengenali teks deskriptif lisan dan tulis tentang orang, binatang, dan benda, siswa dapat mengidentifikasi bentuk teks deskriptif lisan dan tulis, siswa dapat menangkap makna teks deskriptif lisan dan tulis,siswa dapat membuat teks deskriptif lisan dan tulis tentang orang, binatang, dan benda.

Karakteristik siswa berdasarkan observasi dan wawancara dengan siswa diketahui bahwa siswa mampu mengoperasikan komputer dan sangat tertarik menggunakannya dalam pembelajaran. Siswa menghendaki warna-warna yang menarik, terang, dan cerah seperti merah, biru, kuning, dan hijau dalam penggunaan multimedia. Selanjutnya siswa menyukai belajar sambil bermain. Penyampaian pembelajaran yang didukung dengan gambar, musik, dan tulisan-tulisan yang indah lebih disukai siswa daripada hanya teks saja.

Setelah menentukan KI, KD, indikator, dan karakteristik awal siswa tahap selanjutnya yaitu menetukan strategi pembelajaran, Setrategi pembelajaran yang diterapkan dalam pengembangan produk menggunakan pendekatan saintifik sesuai dengan kurikulum 2013 saat ini. Materi yang dipilih yaitu materi teks desktiprif kelas VII untuk SMP/MTs berdasarkan analisis kebutuhan dan karakteristik. Instrumen penilaian berjumlah 10 soal pilihan ganda mencakup KI, KD dan indikator keberhasilan.

Tahap selanjutnya yaitu pengembangan produk. Produk multimedia pembelajaran dikembangkan menggunakan Adobe Flash CS 6 didukung dengan program lainnya seperti Coreldraw, Adobe Photoshop CS6, Adobe Audition, dan Swish Max. Kegiatan yang dilakukan yaitu; (1) membuat flowchart sebagai alur mengembangkan multimedia, (2) mengumpulkan materi teks deskriptif dan juga merekam narasi/ suara berbentuk mp3 yang direkam oleh native speaker, (3) membuat storyboard untuk menggambarkan tampilan setiap frame, (4) memproduksi dan menggabungkan materi berdasarkan storyboard dan flowchart, (5) tes secara modular untuk memastikan hasil awal pembuatan multimedia sesuai flowchart maupun storyboard yang direncanakan. Berikut tampilan-tampilan slide yang ada pada produk yang dikembangkan. 
Tampilan title page berisi indetitas pengembang, judul materi, logo perguruan tinggi (UNY), dan gambar yang relevan dengan topik dapat dilihat pada Gambar 2.

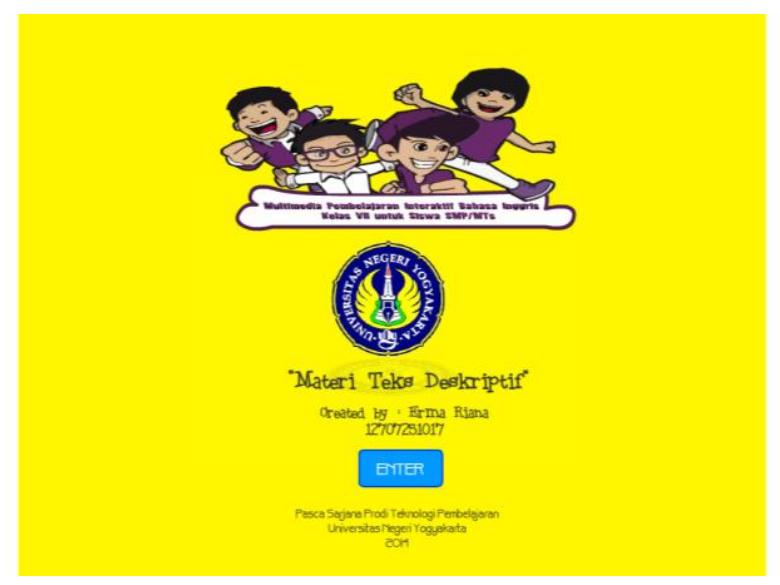

Gambar 2. Tampilan pada title page

Tampilan layar menu materi teks deskritif berisi definisi, describing people, describing things, dan describing animals dapat dilihat pada Gambar 3.

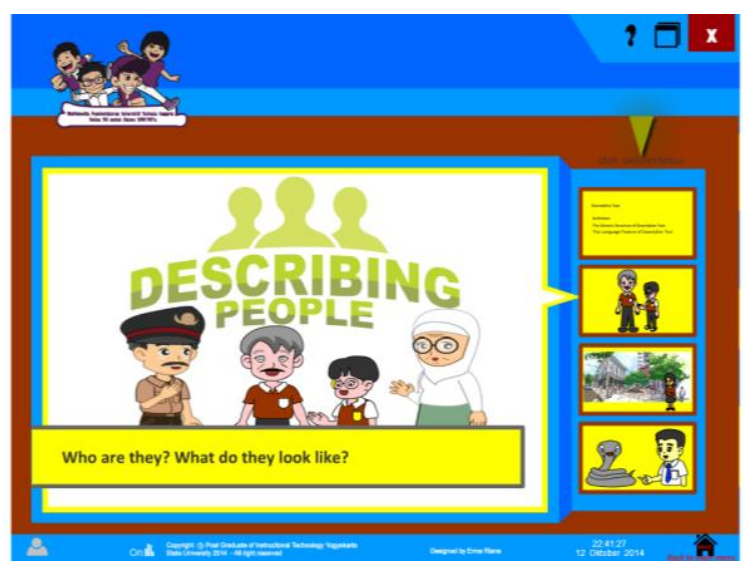

Gambar 3. Tampilan pada menu materi

Setelah multimedia pembelajaran dikembangkan proses selanjutnya yaitu tahap validasi ahli kemudian revisi, uji coba kemudian revisi yang bertujuan untuk menyempurnakan produk. Validasi dilakukan oleh ahli materi Bahasa Inggris dan ahli media. Ahli materi bertujuan untuk menilai produk multimedia pembelajaran pada aspek pembelajaran dan aspek isi sedangkan ahli media bertujuan untuk menilai produk multimedia pembelajaran pada aspek tampilan media dan aspek pemograman.
Validator media mencermati produk multimedia kemudian memberikan penilaian, komentar dan saran berkaitan dengan aspek-aspek yang diberikan. Setelah validasi produk proses selanjutnya yaitu uji coba satu-satu, uji coba kelompok kecil, dan uji coba lapangan hingga menghasilkan produk final.

\section{Hasil Validasi Ahli Materi}

Dalam analisis data hasil validasi produk ahli materi terdapat dua aspek yang dinilai yaitu aspek pembelajaran dan aspek isi. Pada aspek pembelajaran terdapat 15 indikator penilaian, 10 indikator mendapatkan skor 5 (sangat baik), 4 indikator mendapatkan skor 4 (baik), dan 1 indikator mendapatkan skor 3 (cukup). Hasil perhitungan rerata skor pada aspek materi adalah 4,60 dengan kategori sangat baik.

Pada aspek isi terdapat 14 aspek penilaian dengan rincian 9 indikator mendapatkan skor 5 (sangat baik) dan 4 indikator mendapatkan skor 4 (baik). Rerata dari aspek pembelajaran 4,64 dengan kategori sangat baik. Total keseluruhan dari aspek yang dinilai memperoleh kategori sangat baik dengan jumlah 134 dan rerata 4,62. Hasil penilaian ahli materi dapat dilihat pada tabel rangkuman hasil penilaian ahli materi berikut:

Tabel 4. Rekap Hasil Penilaian Ahli Materi

\begin{tabular}{lccc}
\hline No Aspek Penilaian Jumlah & $\begin{array}{c}\text { Rata- } \\
\text { rata }\end{array}$ & Ketegori \\
\hline 1 Pembelajaran & 69 & 4,60 & Sangat Baik \\
2 Isi & 65 & 4,64 & Sangat baik \\
Total Keseluruhan & 134 & 4,62 & Sangat baik \\
\hline
\end{tabular}

\section{Hasil Validasi Ahli Media}

Hasil validasi ahli media pada aspek tampilan mendapatkan skor 4 (baik) dengan rerata skor 4,0 dengan kategori baik dari 11 indikator yang dinilai. Pada aspek pemrograman terdapat 14 aspek penilaian dengan rincian semua aspek 
yang dinilai mendapat skor 4 (baik) dengan rerata 4,0 dengan kategori baik.

Dari dua aspek yang dinilai memperoleh kategori baik dengan jumlah 100 dan rerata 4,0. Hasil tersebut menunjukkan multimedia yang dikembangkan layak untuk uji coba lapangan dengan melakukan revisi sesuai saran ahli media. Rangkuman hasil penilaian ahli media disajikan pada Tabel 5.

Tabel 5. Rekap Hasil Penilaian Ahli Media

\begin{tabular}{clccl}
\hline No & Aspek Penilaian & Jumlah & $\begin{array}{c}\text { Rata- } \\
\text { rata }\end{array}$ & Ketegori \\
\hline 1 & Tampilan media & 44 & 4,0 & Baik \\
2 & Pemrograman & 56 & 4,0 & Baik \\
Total Keseluruhan & 100 & 4,0 & Baik \\
\hline
\end{tabular}

Hasil Uji Coba Satu-satu

Aspek yang dinilai pada tahap ini yaitu aspek pembelajaran, aspek materi, dan aspek tampilan media. Hasil penilaian menunjukkan dari tiga aspek yang dinilai oleh tiga siswa dengan jumlah 11 indikator penilaian memperoleh hasil sangat baik untuk masing-masing aspek. Aspek pembelajaran memperoleh kategori sangat baik dengan jumlah nilai 39 dengan rata-rata 4,33. Pada aspek isi jumlah nilai yang didapat 67 dan rata-rata 4,33 dengan kategori sangat baik. Pada aspek tampilan jumlah nilai 42 dan rata-rata 4,67 dengan kategori sangat baik. Rekap penilaian oleh siswa pada uji coba satu-satu disajikan pada Tabel 6.

Tabel 6. Rekap Hasil Penilaian Siswa Uji Coba Satu-satu

\begin{tabular}{llcrl}
\hline No & Aspek Penilaian & Jumlah & $\begin{array}{c}\text { Rata- } \\
\text { rata }\end{array}$ & Ketegori \\
\hline 1 & Pembelajaran & 39 & 4,33 & Sangat Baik \\
2 & Materi & 67 & 4,33 & Sangat baik \\
3 & Tampilan & 42 & 4,67 & Sangat baik \\
Total Keseluruhan & 148 & 4,44 & Baik \\
\hline
\end{tabular}

Hasil Uji Coba Kelompok Kecil

Aspek yang dinilai yaitu aspek pembelajaran, aspek materi, dan aspek tampilan media. Hasil penilaian menunjukkan dari 11 indikator yang dinilai oleh 9 siswa memperoleh respon positif dengan kategori baik untuk masing-masing aspek dengan rata-rata 4,26 pada aspek pembelajaran, 4,33 untuk aspek isi, dan 4,63 pada aspek tampilan. Hasil rangkuman penilaian oleh siswa pada uji coba kelompok kecil disajikan pada Tabel 7.

Tabel 7. Hasil Uji Coba Kelompok Kecil

\begin{tabular}{lllcl}
\hline No Aspek Penilaian & Jumlah & $\begin{array}{c}\text { Rata- } \\
\text { rata }\end{array}$ & Ketegori \\
\hline 1 Pembelajaran & 115 & 4,26 & Sangat Baik \\
2 Materi & 196 & 4,33 & Sangat baik \\
3 & Tampilan & 125 & 4,63 & Sangat baik \\
Total Keseluruhan & 436 & 4,40 & Baik \\
\hline
\end{tabular}

Hasil Uji Coba Operasional

Analisis Data Hasil Belajar (pre-test dan posttest)

Analisis data hasil belajar siswa dihitung menggunakan teknik standart gain (gain standar), yaitu kenaikan skor diperoleh dengan skor akhir (post-test) dikurangi skor awal (pre-test) kemudian dibagi dengan hasil pengurangan antara skor maksimum dengan skor awal (pre-test). Kriteria efektivitas produk ditentukan berdasarkan hasil pre-test dan post-test siswa dilihat dari jumlah rata-rata kenaikan skor (gain score) seluruh siswa kelas VII yang disajikan pada Tabel 8.

Tabel 8. Tabel 8. Perbandingan Hasil pretest dan post-test siswa

\begin{tabular}{llllll}
\hline No Nilai & $\begin{array}{l}\text { Pre- } \\
\text { test }\end{array}$ & $\begin{array}{l}\text { Post- } \\
\text { test }\end{array}$ & $\begin{array}{l}\text { Gain } \\
\text { Score }\end{array}$ & Kriteria \\
\hline 1 & Nilai terendah & 5,00 & 7,00 & 0,40 & Sedang \\
2 & Nilai tertinggi & 9,00 & 10,00 & 1,00 & Tinggi \\
3 & Total & 217 & 273 & 21,65 & \\
4 & Rata-rata & 7,23 & 9,10 & 0,72 & Tinggi \\
\hline
\end{tabular}

Hasil pre-test dan post-test yang diperoleh siswa bedasarkan tabel ditas diketahui nilai terendah dan nilai tertinggi siswa pada pre-test adalah 3,0 dan 9,00 
dengan jumlah rata-rata 7,23, sedangkan nilai terendah dan tertinggi siswa setelah menggunakan produk (post-test) sebesar 7,00 dan 10,00 dengan rata-rata 9,10. Peningkatan hasil belajar (gain score) siswa setelah menggunakan produk berjumlah 21,65 dengan rata-rata 0,72 termasuk kategori tinggi. Dapat disimpulkan bahwa produk yang dikembangkan efektif digunakan dalam proses belajar mengajar.

\section{Analisis Data Penilaian Siswa Uji Coba Lapangan}

Uji coba lapangan dilaksanakan dengan subjek uji coba berjumlah 30 orang siswa di laboratorium komputer SMPN 3 Kalasan Yogyakarta. Lembar penilaian siswa diberikan setelah siswa menggunakan multimedia pembelajaran. Hasil rangkuman penilaian oleh seluruh siswa disajikan pada Tabel 9.

Tabel 9. Rekap Hasil Penilaian Siswa pada Uji Coba Lapangan

\begin{tabular}{llcll}
\hline No Aspek Penilaian & Jumlah & $\begin{array}{c}\text { Rata- } \\
\text { rata }\end{array}$ & Ketegori \\
\hline 1 Pembelajaran & 370 & 4,11 & Baik \\
2 Materi & 611 & 4,07 & Baik \\
3 Tampilan media & 398 & 4,35 & Sangat baik \\
Total Keseluruhan & 1379 & 4,17 & Baik \\
\hline
\end{tabular}

Ada tiga aspek yang dari produk yang dikembangkan yaitu aspek pembelajaran berjumlah tiga indikator, aspek materi berjumlah lima indikator, dan aspek tampilan berjumlah tiga indikator. Tabel di atas menunjukan siswa memberikan nilai positif atau kategori baik terhadap pernyataan-pernyataan yang diberikan dengan memperoleh rata-rata 4,17 dari tiga aspek yang dinilai. Pada aspek pembelajaran total nilai yang diperoleh yaitu 370 dengan ratarata 4,11 dengan ketegori baik. Hal ini menunjukkan bahwa siswa lebih mengerti dan termotivasi dengan materi yang disampaikan melalui produk multimedia pembelajaran yang dikembangkan.

Pada aspek materi dengan lim indikator yang diberikan total skor diperoleh yaitu 611 dengan rata-rata 4,07 dan memiliki kriteria baik. Artinya kegiatan pembelajaran dengan menggunakan multimedia pembelajaran dirasakan menarik bagi siswa karna terdapat kegiatan-kegiatan pembelajaran yang membuat siswa merasa bermain sekaligus belajar.

Pada aspek tampilan, penilaian siswa berdasarkan tabel diatas memperoleh respon positif dengan kategori sangat baik dengan jumlah skor 398 dengan rata-rata 4,35. Aspek yang dinilai berjumlah tiga indikator. Dari tiga aspek yang dinilai, aspek tampilan merupakan salah satu faktor penting dalam multimedia pembelajaran yang dikembangkan karena membuat siswa lebih tertarik untuk belajar dengan alat bantu pembelajaran yang dikembangkan.

\section{Simpulan dan Saran}

\section{Simpulan}

Hasil penelitian dan pengembangan program multimedia pembelajaran bahasa Inggris materi teks deskriptif diperoleh hasil berupa karakteristik produk yang dihasilkan mencakup kompetensi, materi, glossary, evaluasi, dan games. Kom-petensi terdiri dari kompetensi inti, kompe-tensi dasar, dan indikator keberhasilan. Materi berisi tiga topik utama yaitu describing people, describing things, and describing animals. Evaluasi berbentuk true and false items dan multiple choice items. Games yang disajikan berbentuk permainan tebak kata atau guessing words.

Produk yang dikembangkan layak digunakan sebagai salah satu alat bantu pembelajaran ditinjau dari aspek pembelajaran memperoleh nilai rata-rata 4,60 dengan kategori sangat baik. Aspek isi memperoleh nilai rata-rata 4,64 dengan kategori sangat baik. Aspek tampilan media dan aspek pemrograman memperoleh nilai ratarata masing-masing 4,0 dengan kategori baik. Hasil uji coba satu-satu memperoleh nilai rata-rata 4,44 dengan kategori sangat baik.

Hasil uji coba kelompok kecil memperoleh nilai rata-rata 4,40 dengan kategori 
sangat baik. Hasil uji coba lapangan memperoleh nilai rata-rata 4,17 dengan kategori baik. Peningkatan skor (gain score) rata-rata seluruh siswa dari hasil pretest dan post-test sebesar 0,72 (N-gain $\geq 0,7)$. Hal ini berarti efektivitas pengembangan produk termasuk kategori tinggi.

Saran

Agar produk yang dikembangkan berjalan efektif guru hendaknya menjelaskan terlebih dahulu kepada siswa tentang program dan penggunaannya dengan tujuan siswa lebih mudah memahami materi yang disajikan. Penyampaian materi diawali dengan menjelaskan konsep materi yang bertujuan mengasah kemampuan siswa, memahami dan mengingat materi yang disampaikan.

Saran selanjutnya yaitu siswa membaca dan mempelajari keseluruhan materi secara berurutan dimulai dari kompetensi, materi, glossary, evaluasi, dan games. Diskusikan dengan guru atau teman sebaya apabila terdapat kesulitan dalam menjalankan program atau materi yang tidak dipahami. Selain itu siswa hendaknya terbiasa mengoperasionalkan program dengan tujuan melatih ketrampilan siswa dan mengasah daya ingat siswa mengenai materi yang dipelajari.

Diseminasi dan Pengembangan Produk Lebih Lanjut

Produk multimedia ini dapat dipakai sebagai salah satu sumber belajar bagi siswa dan disebarluaskan di sekolahsekolah SMP/MTs secara langsung ataupun secara elektronik melalui media internet yang diunduh, diduplikasi atau dikemas menggunakan CD bagi siapa saja yang membutuhkan.

Pengembangan program lebih lanjut dapat menambahkan kelengkapan komponen yang belum tersedia seperti penambahan cakupan materi yang lebih luas, penambahan video yang berhubungan dengan materi, tampilan gambar 3D yang menarik dan dinamis sehingga tidak timbul kejenuhan saat menggunakan program. Kemampuan berbicara dan kemampuan menulis sebagai karakteristik dari bahasa Inggris serta penerapan kurikulum melalui pendekaan saintifik pada kegiatan mengeksplorasi dan mengomunikasikan hendaknya dapat diterapkan seutuhnya pada pengembangan program lebih lanjut.

\section{Daftar Pustaka}

Borg, W.R. \& Gall, M.D. (1983). Educational research: an introduction (4th $e d)$. New York, USA: Longman.

Brown, D.H. (200). Principles of language learning and teaching (4th ed). New York, USA: Longman.

Darmawan, D. (2012). Teknologi pembelajaran. Bandung: PT Remaja Rosdakarya Offset.

Dick, W., Carey, L., \& Carey, J.O. (2001). The systematic design of instruction ( $5^{\text {th }}$ ed). New York, USA: Longman.

Gerrot, L and Wignell, P. (1994). Making sense of functional grammar. Australia: Gerd Stable

Hake, R. R (1998). Interactive engagement versus traditional methods: a sixthousand-student survey of mechanics test data for introductory physics course [Versi elektronik]. The American Journal of Physics Research, Am. J. Phys, 64-74.

Hammond, et al. (1992). Englih for special purpose: a handbook for teacher of adult literacy. Sydney: Macquiarie University.

Harmer, J. (2007). The practice of English language teaching ( $4^{\text {th }} \mathrm{ed}$ ). England: Longman.

Khamkhien, A. (2012). Computer assisted language learning and English language teaching in Thailand: Overview [Versi Elektronik]. Mediterranean Journal of Social Sciencies. Vol. 3 (1) 55-64. 
Kemdikbud. (2013). Pembelajaran berbasis kompetensi mata pelajaran bahasa Inggris melalui pendekatan saintifik. Jakarta: Kemdikbud.

Mayer, R.E. (2009). Multimedia learning (2nd ed). New York: Cambridge University Press.

Pachler, N. \& Field, K. (1997). Learning to teach modern foreign languages in the secondary school: a comparison to school experience. London \& New York: Routledge.

Phillips, R. (1997). The developer's handbook to interactive multimedia: a practical guide for educational applications. London: Kogan Page Ltd.

Smaldino, S.E., Lowther, D.L., \& Russel, J.D. (2011). Teknologi pembelajaran dan media untuk belajar. (Terjemahan Arif Rahman). Prentice Hall: Pearson. (Buku asli diterbitkan tahun 2008).

Tompkins, G.E. \& Hoskisson, K. (1995). Language arts ( $3^{\text {rd }}$ ed). Merrill: Prentice Hall.

Towndrow, P.A. \& Vallance, M. (2004). Using IT in the language classroom: a guide for teacher and students in Asia ( $\left.3^{\text {rd }} e d\right)$. Singapore: Longman. 